\title{
CAN CRITICAL TEMPERATURES BE RELATED TO INSECT ORDER?
}

\author{
A. ARBAB ${ }^{1,2}$ and M.R. McNEILL ${ }^{2}$ \\ ${ }^{1}$ Islamic Azad University, Takestan Branch, P.O. Box 34819-49479, Takestan, Iran \\ ${ }^{2}$ AgResearch, Lincoln, Private Bag 4749, Christchurch 8140, New Zealand
}

Corresponding author: arbab.abbas@agresearch.co.nz.

Insect phenology models are widely used for decision support in pest management and more recently in risk assessments. During the last two decades, numerous linear and nonlinear models have been used to describe insect development rates and estimate various critical temperatures (CT) including optimal development temperature $\left(\mathrm{T}_{\mathrm{opt}}\right)$, maximum development temperature $\left(\mathrm{T}_{\max }\right)$, minimum development temperature $\left(\mathrm{T}_{\min }\right)$ and thermal constant $(K)$ (e.g. day degree requirements to complete development). Using a database comprising more than 600 species from laboratory and field experiments, the relationship between CT for the six main insect orders, Coleoptera, Diptera, Hymenoptera, Lepidoptera, Homoptera and Hemiptera, was compared. There were no significant differences $(\mathrm{P}>0.05)$ between $\mathrm{T}_{\text {opt }}$ and $\mathrm{T}_{\max }$ for all orders, but $\mathrm{T}_{\min }$ and $\mathrm{K}$ showed significant $(\mathrm{P}<0.001)$ differences between orders, with Hemiptera and Coleoptera having the highest and Homoptera the lowest $\mathrm{T}_{\min }$ for egg to adult development. Conversely, the thermal constant $(K)$ for egg to adult development was highest for Lepidoptera and lowest for Hymenoptera. A possible explanation for the observed differences in $\mathrm{T}_{\text {min }}$ and $\mathrm{K}$ may relate to trophic level within the insect kingdom. The lack of significant variation of $\mathrm{T}_{\mathrm{opt}}$ and $\mathrm{T}_{\max }$ across orders may simply relate to the models used to calculate these variables, with linear models sometimes fitted to nonlinear temperature dependent development patterns.

\section{REARING AND STORAGE CONDITIONS FOR BURNT PINE LONGHORN (ARHOPALUS FERUS) AND GOLDENHAIRED BARK BEETLE (HYLURGUS LIGNIPERDA)}

\section{C.W. VAN EPENHUIJSEN, K.G. SOMERFIELD AND D.I. HEDDERLEY}

\author{
The New Zealand Institute for Plant \& Food Research Limited, \\ Private Bag 11600, Palmerston North 4442, New Zealand \\ Corresponding author: vanepenhuijsenk@crop.cri.nz.
}

The longevity of forestry insects used in fumigation trials was investigated in the laboratory. Different life stages must sometimes be maintained for several weeks before trials can start. If insects can be stored with confidence then field collection can be made whenever seasonal and or daily weather conditions are suitable. Burnt pine longhorn adults collected from log export ports were kept at $8,12,16$ and $20^{\circ} \mathrm{C}$. Surviving adults were counted every other day. Those held at $8^{\circ} \mathrm{C}$ survived on average 21.4 days compared with 4.3 days at $20^{\circ} \mathrm{C}$. Fresh burnt pine longhorn eggs were stored at $1,5,8$ and $12^{\circ} \mathrm{C}$ for 5 weeks. Those stored at $12^{\circ} \mathrm{C}$ produced over $60 \%$ larval emergence whereas those at 1 and $5^{\circ} \mathrm{C}$ had only 3-6\% emergence after 3 weeks. Burnt pine longhorn were reared from eggs at $12,15,18$ and $20^{\circ} \mathrm{C}$ using an artificial diet. Burnt pine longhorn larvae increased in mean weight from $4.2 \mathrm{mg}$ to $511.7 \mathrm{mg}$ over 120 days at $20^{\circ} \mathrm{C}$. Below $18^{\circ} \mathrm{C}$ no larvae survived beyond 56 days. Small goldenhaired bark beetle larvae were reared on the same diet at 12,16 and $20^{\circ} \mathrm{C}$. A few larvae grew into adults at $20^{\circ} \mathrm{C}$. 